\title{
Equity Carve-Outs And Changes In Corporate Control
}

Heather M. Hulburt, Ph.D., (Email: hhulburt@wvu.edu), West Virginia University

\begin{abstract}
This study proposes a corporate control hypothesis in which equity carve-outs facilitate changes in corporate control by providing an economical means to transfer control of corporate assets to bidders who will potentially create greater value. Consistent with this hypothesis, a statistically significant $16 \%$ of the equity carve-outs in this study's sample are taken over within six years. Those equity carve-outs subsequently taken over appear to be economically different from those motivated by other reasons. Parent firms of equity carve-outs subsequently taken over display a significantly greater share price reaction to the announcement of an equity carve-out than do parent firms of equity carve-outs not subsequently taken over. For those carve-outs subsequently taken over, an important factor contributing to parent firm gains is the relative size of the carveout IPO. There appears to be an optimal retention level of 10-50\% for carve-outs motivated by the intent to facilitate a change in corporate control.
\end{abstract}

\section{Introduction}

10

quity carve-outs are partial public offerings whereby common shares of wholly owned subsidiaries are sold to the public. Unlike other forms of restructuring, equity carve-outs seldom result in any immediate change in control of the subsidiary because the parent firm usually retains a majority ownership stake in its subsidiary. Studies show that equity carve-outs produce positive announcement period stock price reactions for parent firms, yet the sources of these gains have not been fully explored (see Schipper and Smith (1986); Slovin, Sushka, and Ferraro (1995); and Allen and McConnell (1998)). The most offered theories are: (1) signaling and (2) reductions of agency costs. Nanda (1991), in an extension of the Myers and Majluf (1984) signaling model, hypothesizes that firms raise capital through equity carve-outs when parent firm shares are undervalued and subsidiary shares are overvalued. The good news for investors is that the parent shares are not overvalued relative to the subsidiary, and this leads to an increase in parent share price. In support of the Nanda (1991) model, Slovin, Sushka, and Ferraro (1995) find that share prices of equity carve-out rival firms react negatively to carve-out announcements.

In the spirit of Lang, Poulsen, and Stulz (1995), Allen and McConnell (1998) propose that, because of the agency costs associated with managerial control of discretionary capital, the market will discount the gains in carveouts in which management indicates that funds will be retained. Consistent with their hypothesis, the authors find that average excess stock returns to parent firms are significantly more positive when proceeds of the carve-out are paid out rather than retained.

In this paper, I investigate a third possible explanation for equity carve-out gains. I hypothesize that investors' expectations of future takeover activity in carved-out subsidiaries positively affect parent firm share price reactions to announcements of equity carve-outs.

Readers with comments or questions are encouraged to contact the author via email. 
Equity carve-outs are similar to spin-offs; both are forms of corporate divestitures. While equity carve-outs are partial public offerings of wholly-owned subsidiary stock, spin-offs are distributions of subsidiary stock to parent firm shareholders. Studies of both types of corporate divestiture announcements find parent share price reactions of comparable magnitudes, ranging from $1.32 \%$ to $3.34 \%$ for spin-offs and $1.23 \%$ to $2.12 \%$ for equity carve-outs (see Miles and Rosenfeld (1983); Schipper and Smith (1983); Hite and Owers (1983); Slovin, Sushka, and Ferraro (1995); Schipper and Smith (1986); and Allen and McConnell (1998)). Cusatis, Miles, and Woolridge (1993) find that spin-offs experience a high incidence of takeovers (14\% of their spin-off sample is taken over within 3 years' time) and that a primary motivation for spin-offs is facilitating such takeovers. Because of the similarities between spin-offs and carve-outs, I investigate whether this is also true for equity carve-outs. (See Jensen and Ruback (1983) for a survey of studies on target firm gains from takeovers.)

Like spin-offs, equity carve-outs could facilitate takeovers by providing a low-cost method of transferring control of corporate assets to bidders who will create greater value. By splitting companies into separate businesses, equity carve-outs allow bidders who are able to create more value to avoid the expense of taking over whole entities. Consistent with this argument, I find that $16 \%$ of the equity carve-outs in my sample are taken over within six years. This number is statistically greater than the $9 \%$ of matched firms found to be taken over within the same six-year period.

Similar to previous equity carve-out studies, I find that parent firms, on average, display a positive and significant share price reaction to the announcement of an equity carve-out. However, those equity carve-outs subsequently taken over appear to be economically different from those motivated by other reasons. Parent firms of equity carve-outs that are subsequently taken over display a significantly greater share price reaction to the announcement of an equity carve-out than do parent firms of equity carve-outs that are not subsequently taken over. ${ }^{1}$ It is possible that the two sets of carve-outs differ in terms of, for example, size, growth, profitability, and/or relatedness to the parent firm's industry.

For those carve-outs subsequently taken over, an important factor contributing to parent firm gains is the relative size of the carve-out IPO. Gilson, Healy, Noe, and Palepu (2001) find significant improvement in both the accuracy and consensus of analysts' earnings forecasts following stock break-ups, which lends support for the idea that potential bidders will be better informed (and more forthcoming with bids) subsequent to a sizeable carve-out. Another point in favor of the parent firm selling a large proportion of its carve-out to the public is the mitigation of holdout problems that might exist if the parent firm were to retain "too much" of the carved-out subsidiary. When faced with a valuable takeover bid, the parent firm might, for example, prevent the takeover from going through, choosing instead to hold out for a better offer in the future. (See Gilson, John, and Lang (1990); Chatterjee, Dhillon, and Ramirez (1995); and James (1996) for studies of holdout problems in the area of debt restructuring.) Parents will want to retain enough of the carve-out, however, to benefit from future takeover premia.

Consistent with the above, I find that the higher the proportion of the carve-out sold to the market, up to a point, the higher the gains to parent firm shareholders. An important implication of this investigation is that there appears to be an optimal retention level of carve-out IPOs motivated by the intent to facilitate a change in corporate control. For those parents retaining 10-50\% of their subsidiaries, gains to shareholders are highest.

The next section describes the sample. Sections 3 and 4 report the results of the empirical analysis. Sections 5 and 6 provide conclusions and suggestions for future research.

\section{Sample selection and description}

\subsection{Sample selection procedure}

To generate a sample of equity carve-outs, I examined the Securities Data Company and the Investment Dealers' Digest for initial public offerings involving a corporate issuer during the period 1981-1994; I found a net total of 593 initial public offerings (IPOs) involving a corporate issuer. I consulted the Wall Street Journal, the Wall Street 
Journal Index, the Directory of Corporate Affiliations, and America's Corporate Families to identify parent firm names. To be included in the sample, I required: (1) that the event involve an initial public offering of common stock in a previously wholly-owned subsidiary of a corporation traded on the NYSE/AMEX or NASDAQ, (2) that the subsidiary be a domestic corporation, and (3) that the parent and subsidiary have CRSP and Compustat data available. My search resulted in a final sample of 172 verified equity carve-outs for the period 1981-1994.

For the final sample, I searched the Dow Jones News Retrieval and individual firm prospectuses to obtain the announcement dates of the equity carve-out, the price per share of the initial public offering, the number of shares offered, the type of offering (primary, secondary, or joint), the use of the proceeds, and the percentage of shares retained by the parent firm. I used the CRSP daily return files to obtain market values and security returns.

\subsection{Descriptive statistics}

Table 1 reports descriptive statistics for the final carve-out sample. Panel A presents the distribution of equity carve-outs by year. The distribution is somewhat uniform, with at least five and at most 27 events occurring in any given year. Panel B reports the mean and median parent and subsidiary market values in the year of the carve-out. Market value is calculated as the price per share times the number of shares outstanding. For the full sample, the mean (median) parent market value is $\$ 606,991$ million ( $\$ 3,134.15$ million); these numbers are $\$ 179,782$ million ( $\$ 543.75$ million) for the subsidiary. The skewness in these size variables (mean market values are substantially higher than median market values) indicates that there are a small number of very large-sized firms engaging in equity carve-outs. For example, in 1989, Atlantic Richfield (ARCO) sold shares in its wholly-owned subsidiary, Lyondell Petrochemical. Proceeds of the sale were $\$ 1.29$ billion, making it the second largest initial public offering ever.

Panel C of Table 1 depicts a breakdown of the percentage of carved-out common stock the parent firm retains immediately subsequent to the equity carve-out. Seventy-six percent of the parents retain a $50 \%$ or greater share in their respective subsidiaries, and thirty-five percent of the parents retain an $80 \%$ or greater share. ${ }^{2}$ Panel D provides a breakdown of use of proceeds (paid out to shareholders and/or creditors or retained) by offering type (primary, secondary, or joint). If the subsidiary alone collects the proceeds of the sale, then I refer to the offering as a primary offering. If the parent firm alone collects the proceeds of the sale, then I refer to the offering as a secondary offering. If both the subsidiary and the parent firm collect the proceeds of the sale, then I refer to the offering as a joint offering. As depicted here, although carved-out subsidiaries exact at least a portion of the proceeds of sale in a large majority of cases, the carved-out subsidiaries tend to use the proceeds they collect to repay debt owed to their parents or other creditors, or to pay a special dividend to their parents.

Table 2 provides information on the survivorship status of equity carve-outs and a set of matching firms (Panel A) as well as an aging table (Panel B) for those carve-outs and matching firms subsequently taken over within six years of the carve-out IPO. Consistent with other equity carve-out studies, equity carve-outs appear to be temporary events. Only 50\% (86 of the 172) survive. In 34 of the events, the carve-out is bought back by its parent, 1 event results in a spin-off of the carve-out, and in $16 \%$ of the equity carve-out events (28 of the 172), the carved-out subsidiary is subsequently taken over by another firm.

The matching firm sample is constructed in the same manner as in Cusatis, Miles, Woolridge (1993). Sample firms are matched on industry (4-digit SIC code) and size (market value). Only 9\% of the matched firm sample is taken over within the six-year period. This number is statistically different from the number of carve-outs taken over ( $\mathrm{p}=0.0322)$. Thus, just like spin-offs, carve-outs tend to be taken over more often than their counterparts.

For those carve-outs taken over within six years, the mean number of years between the time the carve-out goes public and the time it is subsequently taken over is 2.93 years; the median number of years is 3 years. Therefore, on average, equity carve-outs subsequently taken over do not remain in the market for long. 
Table 1

Descriptive statistics for 172 equity carve-out events over the 1981-1994 period.

Panel A: Distribution of carve-out events by year

\begin{tabular}{|c|c|c|c|c|c|c|c|c|c|c|c|c|c|c|}
\hline $\mathrm{N}$ & '81 & '82 & '83 & '84 & '85 & '86 & '87 & '88 & '89 & '90 & '91 & ‘92 & '93 & '94 \\
\hline 172 & 10 & 6 & 7 & 5 & 5 & 19 & 14 & 8 & 9 & 7 & 22 & 16 & 27 & 17 \\
\hline
\end{tabular}

\begin{tabular}{|c|c|c|c|c|}
\hline \multirow[t]{2}{*}{ Panel B: } & \multicolumn{4}{|c|}{ Mean and median parent and subsidiary market values ${ }^{\text {a }}$} \\
\hline & Parent & Parent & Subsidiary & Subsidiary \\
\hline & Mean MV & Median MV & Mean MV & Median MV \\
\hline$\underline{\mathrm{N}}$ & (\$ millions) & (\$ millions) & (\$ millions) & (\$ millions) \\
\hline $1 \overline{7} 2$ & 606,991 & $3,134.15$ & 179,782 & 543.75 \\
\hline
\end{tabular}

Panel C: $\quad$ Breakdown of percentage of common stock retained by parent firm

\begin{tabular}{lllllllll}
\hline \\
\hline 172 & $\frac{\mathrm{N}}{31}$ & $\frac{40-49}{9}$ & $\frac{50-59}{26}$ & $\frac{60-69}{17}$ & $\frac{70-79}{27}$ & $\frac{80-89}{54}$ & $\frac{90-99}{8}$
\end{tabular}

\begin{tabular}{crc}
\hline Panel D: & Breakdown of type of use of proceeds, by offering type ${ }^{\mathbf{b}, \mathbf{c}}$ & \\
\hline & Secondary Offering & Primary Offering
\end{tabular}

\begin{tabular}{|c|c|c|c|c|c|c|c|}
\hline$\frac{N}{172}$ & $\frac{\text { Paid Out }}{11}$ & $\frac{\text { Retained }}{26}$ & $\begin{array}{c}\begin{array}{c}\text { Paid Out } \\
\text { to Creditors }\end{array} \\
\frac{26}{}\end{array}$ & $\begin{array}{l}\text { Paid Out } \\
\text { to Parent } \\
38\end{array}$ & $\frac{\text { Retained }}{50}$ & $\frac{\text { Paid Out }}{9}$ & $\frac{\text { Retained }}{12}$ \\
\hline
\end{tabular}

a Market value (share price * shares outstanding) is calculated at the end of event year 0.

b A primary offering indicates that the subsidiary received all proceeds of the sale, a secondary offering indicates that the parent firm received all proceeds of the sale, and a joint offering indicates that both the subsidiary and the parent firm received some portion of the proceeds of the sale.

c Proceeds are deemed "paid out" if they are paid out to either shareholders or creditors; otherwise, proceeds are deemed "retained".

d In two cases, the carve-out firms pay out their portion of the proceeds to their parent firms.

Table 2

Survivorship status and aging table

Survivorship status and aging tables for 172 equity carve-outs and their matched firms. Aging tables are for firms taken over within six years of the carve-out IPO.

\begin{tabular}{lcccccc}
\hline \multicolumn{1}{l}{ Panel A: Survivorship status } & \multicolumn{1}{l}{} & & \\
& $\mathrm{N}$ & Survive & Bought back by parent & $\begin{array}{c}\text { Taken } \\
\text { over }\end{array}$ & $\begin{array}{c}\text { Spun } \\
\text { off }\end{array}$ & Other $^{\text {a }}$ \\
\hline Carve-outs & 172 & 86 & 34 & $28^{* *}$ & 1 & 23 \\
\hline Matched firms & 172 & 146 & 0 & 15 & 0 & 11 \\
\hline
\end{tabular}

Panel B: Aging table

Number of years between the time the carve-out first went public to the time the carve-out was taken over. ${ }^{\mathrm{b}}$

\begin{tabular}{llllllll} 
& $\mathrm{N}$ & 1 & 2 & 3 & 4 & 5 & 6 \\
\hline Carve-outs & 28 & 8 & 5 & 5 & 4 & 3 & 3 \\
\hline Matched firms & 15 & 5 & 1 & 4 & 1 & 3 & 1
\end{tabular}

a These firms are dropped from CRSP subsequent to the carve-out going public.

b All time periods where partial years are represented are rounded up to the next whole number.

**This proportion is significantly different $(\mathrm{p}=0.032)$ from the proportion of matched firms taken over during the same six-year period. 


\section{Evidence}

It has been established in this paper that equity carve-outs tend to be temporary events, with subsequent takeovers of carved-out subsidiaries common. I argue that investors are able to ascertain in advance which equity carveouts will eventually be taken over and which will not, and I hypothesize that these expectations positively affect parent firm share price reactions to announcements of equity carve-outs. ${ }^{3}$ As evidence in support of this hypothesis, I present parent firm share price reactions to announcements of equity carve-outs and show that, depending on the existence of future takeover activity, these reactions differ.

\subsection{Methodology}

I estimate parent firm share price reactions to announcements of equity carve-outs by calculating excess stock returns. The market model is estimated for the stock returns of each sample firm over the 90 trading days ending 121 days before the offering announcement. The estimated market model parameters are used to compute cumulative prediction errors for the two-day event window $(-1,0)$, where event day zero is the earlier of (1) the filing date, or (2)

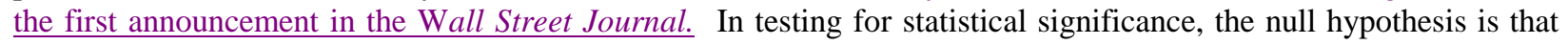
the average cumulative prediction error equals zero. The test statistic is the ratio of the average prediction error to its standard deviation estimated over the pre-event period (-210 to -121).

\subsection{Empirical results}

Table 3 reports event study results for the full parent firm sample and for two parent firm subsamples: (1) parents of carve-outs subsequently taken over within six years, and (2) parents of carve-outs not subsequently taken over within six years. I use the six-year cutoff for two reasons. First, the most recent carve-outs in the sample have a followup period of just six years. Second, it is unlikely that investors will foresee the subsequent takeover of a carve-out more than six years in advance.

For the full sample, the mean and median stock price returns over the $(-1,0)$ event window are $1.63 \%$ and $1.06 \%$, respectively; both are statistically significant at the $1 \%$ level. For those parents of carve-outs not taken over within six years, the mean and median returns are $1.26 \%$ and $0.80 \%$, respectively, with both the mean and median statistically significant at the $1 \%$ level. The mean and median returns for those parents of carve-outs taken over within six years are $3.55 \%(\mathrm{p}=0.02)$ and $1.93 \%(\mathrm{p}=0.00)$, respectively. A test for normality of returns rejects the null. Therefore, I focus on median returns rather than mean returns. Even though the medians of both parent firm subsamples are positive and significant at the $1 \%$ level, a difference of medians test yields a significant difference between these two groups. Consequently, the results support my hypothesis. Parent firms of carve-outs taken over within six years of the carve-out event react more positively to the announcement of an equity carve-out than do parent firms of carve-outs not taken over within six years.

\subsection{The relative size of the carve-out IPO}

There are sound reasons to suspect that the relative proportion of the carve-out sold to the public has an effect on the magnitude of future takeover activity. I argue that in order to generate a market for future takeover activity in the carve-out, it is essential that the parent firm put a relatively large portion of the carve-out into public hands, while still retaining enough to benefit from future takeover premia. Gilson, Healy, Noe, and Palepu (2001) find significant improvement in both the accuracy and consensus of analysts' earnings forecasts following stock break-ups, which lends support for the idea that potential bidders will be better informed (and more forthcoming with bids) subsequent to a sizeable carve-out. Selling enough of the carve-out to the public will ensure that accurate and homogeneous earnings forecasts are available to potential bidders.

Another point in favor of the parent firm selling a large proportion of its carve-out to the public is the mitigation of holdout problems that might exist if the parent firm were to retain "too much" of the carved-out subsidiary. When faced with a valuable takeover bid, the parent firm might, for example, prevent the takeover from 
going through, choosing instead to hold out for a better offer in the future. Gilson, John, and Lang (1990); Chatterjee, Dhillon, and Ramirez (1995); and James (1996) discuss holdout problems at length in the area of debt restructuring.

\subsection{The relative size of the carve-out IPO}

There are sound reasons to suspect that the relative proportion of the carve-out sold to the public has an effect on the magnitude of future takeover activity. I argue that in order to generate a market for future takeover activity in the carve-out, it is essential that the parent firm put a relatively large portion of the carve-out into public hands, while still retaining enough to benefit from future takeover premia. Gilson, Healy, Noe, and Palepu (2001) find significant improvement in both the accuracy and consensus of analysts' earnings forecasts following stock break-ups, which lends support for the idea that potential bidders will be better informed (and more forthcoming with bids) subsequent to a sizeable carve-out. Selling enough of the carve-out to the public will ensure that accurate and homogeneous earnings forecasts are available to potential bidders.

Another point in favor of the parent firm selling a large proportion of its carve-out to the public is the mitigation of holdout problems that might exist if the parent firm were to retain "too much" of the carved-out subsidiary. When faced with a valuable takeover bid, the parent firm might, for example, prevent the takeover from going through, choosing instead to hold out for a better offer in the future. Gilson, John, and Lang (1990); Chatterjee, Dhillon, and Ramirez (1995); and James (1996) discuss holdout problems at length in the area of debt restructuring.

To investigate whether there is a direct relation between parent firm gains and the relative size of the carveout IPO, I create a variable, RELSIZE, which measures the relative size of the carve-out IPO. RELSIZE is defined as follows.

$$
\text { RELSIZE }=\left[\frac{(\text { Fraction of subsidiary sold }) *(\text { Carveout market value in year } 0)}{\text { Parent market value in year }-1}\right]
$$

Employing OLS regression analysis, I find that RELSIZE is significantly positively related to gains to parents of carve-outs taken over $(\mathrm{p}=0.04)$, and to gains to parents of carve-outs not eventually taken over $(\mathrm{p}=0.02)$. These results are reported in Table 4.

To capture the full economic significance of this finding, I run a third regression that includes an interactive term, RELSIZE*TAKEOVER DUMMY, where the takeover dummy is set to zero for the parents of carve-outs not taken over and one for the parents of carve-outs taken over. The coefficient on RELSIZE alone, the value for the non-takeover group, is significant at the $1 \%$ level. The coefficient for the takeover group is the sum of the coefficients of RELSIZE alone and the interaction term. The takeover group is positively affected by RELSIZE, as well, with a coefficient of 0.0139 . Table 4 reports these results.

While it is not surprising to find a direct relation between RELSIZE and parent firm gains, if parent firms divest themselves of $100 \%$ of their subsidiaries, they will likely forego valuable future takeover premia. In addition, if parent firms divest themselves of more than $50 \%$ of their subsidiaries, they will forego the tax and reporting advantages associated with retention levels of $80 \%$ and 50\%, respectively. Thus, I argue that there must be some optimal retention level range over which parent firms can generate interest in the subsidiary, while at the same time retain the ability to cash in on future takeover premia (and possibly benefit from tax and reporting advantages). 
Table 3

Parent firm announcement period returns, classified by takeover activity

Excess common stock returns for 172 parent firms for the $(-1,0)$ event window, where the event day zero is the earlier of $(1)$ the filing date, or (2) the first announcement in the Wall Street Journal. ${ }^{a}$

\begin{tabular}{|c|c|c|c|c|}
\hline \multicolumn{5}{|c|}{ Parent firms classified by whether the carve-out is taken over within six years } \\
\hline & $\begin{array}{l}\text { Full Sample } \\
\text { taken over }\end{array}$ & $\begin{array}{l}\text { Carve-out } \\
\text { not subsequently } \\
\text { taken over } \\
\text { within six years }\end{array}$ & $\begin{array}{l}\text { Carve-out } \\
\text { subsequently } \\
\text { means, } \\
\text { within six years }\end{array}$ & $\begin{array}{l}\text { Difference } \\
\text { of } \\
\text { medians }\end{array}$ \\
\hline $\begin{array}{l}\text { Mean } \\
t \text {-statistic p-value }{ }^{b} \\
\text { Median } \\
\text { Sign rank p-value } \\
\mathrm{N}\end{array}$ & $\begin{array}{l}1.63 \% \\
(0.00)^{* * *} \\
1.06 \% \\
(0.00)^{* * *} \\
172\end{array}$ & $\begin{array}{l}1.26 \% \\
(0.00)^{* * * *} \\
0.80 \% \\
(0.01)^{* * *} \\
144\end{array}$ & $\begin{array}{l}3.55 \% \\
(0.02)^{* *} \\
1.93 \% \\
(0.00)^{* * *} \\
28\end{array}$ & $\begin{array}{l}(0.04)^{* *} \\
(0.02)^{* *}\end{array}$ \\
\hline 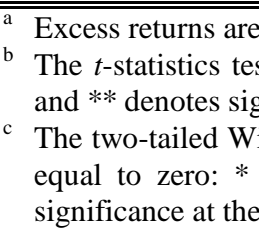 & $\begin{array}{l}\text { culated using the } \\
\text { he hypothesis tha } \\
\text { icance at the } 5 \% \\
\text { xon signed rank } \\
\text { hotes significanc } \\
6 \text { level. }\end{array}$ & $\begin{array}{l}\text { model, where }(-21 \\
\text { ean holding-period } \\
\text { *** denotes sign } \\
\text { (Sign Rank) test } t \\
10 \% \text { level, and }\end{array}$ & $\begin{array}{l}\text { serves as the est } \\
\text { ns equal zero: } * \\
\text { ce at the } 1 \% \text { level. } \\
\text { ll hypothesis that } \\
\text { enotes significano }\end{array}$ & $\begin{array}{l}\text { period. } \\
\text { significance at the } 10 \% \text { level, } \\
\text { dian industry-adjusted rates are } \\
\text { e } 5 \% \text { level, and } * * * \text { denotes }\end{array}$ \\
\hline
\end{tabular}

Table 4

Regression analysis of parent firm excess returns over the event window (-1,0)

OLS regression analysis of parent firm returns where the $(-1,0)$ event window excess returns serve as the dependent variable. Explanatory variables include a measure of the relative size of the equity carve-out, denoted RELSIZE, and an interactive term, denoted RELSIZE*TAKEOVER DUMMY. RELSIZE is defined as the ratio of ((the percentage of the subsidiary sold to the public in the IPO) times (the carve-out's market value in event year zero) to (the parent firm's market value in event year minus 1)). TAKEOVER DUMMY is a dummy variable with a value of one if the carve-out is taken over within six years and zero otherwise. Ttest statistics p-values are given in parentheses below each regression parameter estimate. A* indicates significance at the $10 \%$ level, a ** indicates significance at the $5 \%$ level, and a $* * *$ indicates significance at the $1 \%$ level.

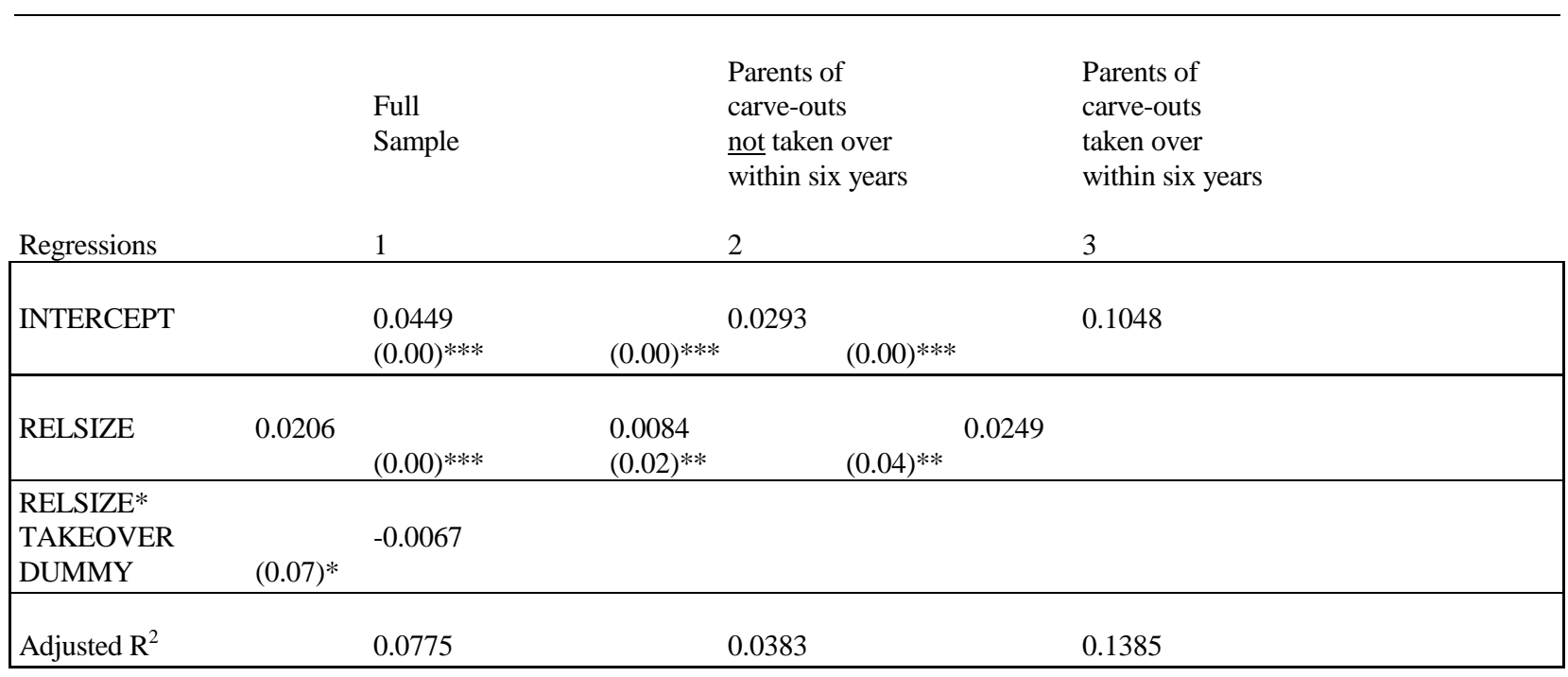


To test, I create four retention level groups: (1) $0-10 \%$, (2) $10-50 \%$, (3) $50 \%-80 \%$, and (4) $80-100 \%$. There are clear legal and tax justifications for using $50 \%$ and $80 \%$ retention levels to separate groups. As mentioned earlier, by retaining at least 50\%, the parent firm can consolidate the subsidiary for financial reporting purposes. By retaining at least $80 \%$, the parent firm can consolidate the subsidiary for tax purposes, and can obtain a $100 \%$ dividend-received tax deduction. While the $10 \%$ break point is somewhat arbitrary, it does represent the point at which the parent still maintains a controlling interest in its carved-out subsidiary. Unfortunately, there is no clearly better approach to partitioning the $0-50 \%$ range. Sample sizes in this range are so small, that attempting to further divide this range into more than two groups would result in sample sizes of close to zero.

Interestingly, I find that for the group of parents whose carve-outs are not taken over, there is no significant difference among the retention level ranges. But for the group of parents whose carve-outs are taken over, there are significant differences among the retention level ranges. The magnitude of gains to parents increases up to the 50\% level, and then falls in the $50-80 \%$ and $80-100 \%$ ranges. Gains to parents are highest when the retention level is in the range of $10-50 \%$ (mean=21.43\%) and lowest when the retention level is in the range of $0-10 \%$ (mean $=-0.31 \%)$. These results imply that there is an optimal retention level range of $10-50 \%$. For firms with the intent of seeking takeover bids for their carved-out subsidiaries, selling 10-50\% of the carve-out in the initial public offering yields the highest gains at the announcement of the IPO. Table 5 reports these results.

Table 5

\section{Parent firm announcement period returns, classified by takeover activity and RETAIN ${ }^{\text {a }}$}

Mean excess common stock returns for 172 parent firms for the $(-1,0)$ event window, where the event day zero is the earlier of (1) the filing date, or (2) the first announcement in the Wall Street Journal. ${ }^{b}$

\begin{tabular}{llll}
\hline Full & Parents of & Parents of \\
sample & carve-outs & carve-outs \\
not taken over & taken over \\
within six years & within six years \\
\hline
\end{tabular}

\section{RETAIN}

\begin{tabular}{lllll} 
Range: & \multicolumn{5}{l}{} \\
\hline $0-10 \%$ & Mean & $0.78 \%$ & $1.01 \%$ & $-0.31 \%$ \\
& $\mathrm{~N}$ & 17 & 12 & 5 \\
\hline $10-50 \%$ & Mean & $3.04 \%$ & $1.29 \%$ & $21.43 \%$ ** \\
& $\mathrm{N}$ & 23 & 20 & 3 \\
\hline $50-80 \%$ & Mean & $1.28 \%$ & $1.01 \%$ & $4.14 \%$ \\
& $\mathrm{~N}$ & 70 & 64 & 6 \\
\hline $80-100 \%$ & Mean & $1.76 \%$ & $1.64 \%$ & $2.14 \%$ \\
& $\mathrm{~N}$ & 62 & 48 & 14 \\
\hline
\end{tabular}

${ }^{\text {a }}$ RETAIN is defined as the percentage of the subsidiary's common stock retained by the parent firm.

${ }^{\mathrm{b}}$ Excess returns are calculated using the market model, where $(-210,-121)$ serves as the estimation period.

**This mean is significantly different (at the $2.5 \%$ level) from the means in all other ranges, and none of the other means are significantly different from each other. 


\section{4. $\quad$ Additional tests}

Section 3 demonstrates that those equity carve-outs subsequently taken over are economically different from those motivated by other reasons. Parent firms of equity carve-outs that are subsequently taken over display a significantly greater share price reaction to the announcement of an equity carve-out than do parent firms of equity carve-outs that are not subsequently taken over. In this section, I position my result in the context of (other) leading explanations of equity carve-outs.

\subsection{The corporate control hypothesis and signaling theory}

Nanda (1991) hypothesizes that firms raise capital through equity carve-outs when parent firm shares are undervalued and subsidiary shares are overvalued. Hence, his model suggests that parent firms should exact higher returns when their subsidiaries are overpriced at the initial public offering, because selling shares of the subsidiary rather than the parent firm indicates that parent firm shares are not overpriced. If this is the only explanation for parent firm gains, then we would expect less takeover activity in those equity carve-outs that are associated with higher parent firm gains, since these equity carve-outs are likely to be the overpriced ones. My results are not consistent with his story. I find that those equity carve-outs that are taken over are associated with the higher parent firm gains.

Moreover, while the corporate control hypothesis yields a plausible explanation for the results in Table 4 (the relative size of the carve-out is positively related to parent firm gains for carve-outs taken over), we would not expect these results under Nanda's (1991) signaling model. In fact, if the equity carve-out is overpriced, as Nanda's model suggests, we would expect the relative size measure to be negatively related to the gains to parent firm shareholders, not positively related.

\subsection{The corporate control hypothesis and the managerial discretion hypothesis}

Allen and McConnell (1998) suggest that we should see a difference in returns to parent firm shareholders depending on whether the parent retains the IPO proceeds. If parents retain the proceeds, returns should be lower than if the proceeds are paid out, due to agency costs. If this is the only explanation of equity carve-outs, then we should not see a difference, on average, between the returns to shareholders when the firm retains (pays out) the proceeds of the IPO and (1) a subsequent takeover occurs versus (2) a subsequent takeover does not ensue. Likewise, we should see a difference, on average, between the returns to shareholders when a subsequent takeover occurs (does not occur) and (1) proceeds of the IPO are paid out versus (2) proceeds of the IPO are retained.

I perform difference of median tests for the scenarios listed above. My results, reported in Table 6, support both the corporate control hypothesis and the managerial discretion hypothesis. For the payout group, there is no significant difference between carve-outs subsequently taken over and carve-outs not subsequently taken over. However, for the retention group, carve-outs not taken over have a median return of $0.37 \%$; carve-outs taken over have a median return of $2.04 \%$. The difference between these medians is statistically significant at the $1 \%$ level, lending additional support for the corporate control hypothesis. Additionally, I find statistical differences between the payout group and the retention group for the no-takeover group, but not for the takeover group. In the notakeover subsample, those cases where IPO proceeds are paid out yield significantly higher returns to parents than those cases where IPO proceeds are retained $(\mathrm{p}=0.06)$. For the overall payout group, the median return is $2.02 \%$, and for the overall retention group, the median return is $0.75 \%$. For those carve-outs not taken over, if proceeds were paid out (retained), median returns are $2.22 \%(0.37 \%)$. For those carve-outs taken over, if proceeds were paid out (retained), median returns are $1.83 \%(2.04 \%)$.

Taken together, my results support the corporate control hypothesis, even after taking into consideration the managerial discretion hypothesis. Strengthening this argument, Allen and McConnell's (1998) managerial discretion hypothesis would not predict the results in Table 4, where I report that the relative size of the carve-out is positively related to parent firm gains for carve-outs taken over. In fact, under the managerial discretion hypothesis, we could 
expect the relative size measure to be positively related to the gains to parent firm shareholders where proceeds are paid out, but negatively related to the gains to parent firm shareholders where proceeds are retained. I check to see if this is the case (results not reported); I find that the coefficient on the relative size measure is significantly positive regardless of whether proceeds are paid out or retained ( $\mathrm{p}=0.00$ in both cases).

Table 6

Parent firm announcement period returns, classified by use of proceeds and takeover activity

Excess common stock returns for 172 parent firms for the $(-1,0)$ event window, where the event day zero is the earlier of $(1)$ the filing date, or (2) the first announcement in the Wall Street Journal. ${ }^{a}$

Panel A: Parent firm payout sample classified by takeover activity in the carve-out

\begin{tabular}{|c|c|c|c|c|}
\hline & $\begin{array}{l}\text { Full } \\
\text { payout } \\
\text { sample }\end{array}$ & $\begin{array}{l}\text { Carve-out } \\
\text { not subsequently } \\
\text { taken over } \\
\text { within six years }\end{array}$ & $\begin{array}{l}\text { Carve-out } \\
\text { subsequently } \\
\text { taken over } \\
\text { within six years }\end{array}$ & $\begin{array}{l}\text { Difference } \\
\text { of } \\
\text { means, } \\
\text { medians }\end{array}$ \\
\hline $\begin{array}{l}\text { Mean } \\
t \text {-statistic p-value }{ }^{\mathrm{b}} \\
\text { Median } \\
\text { Sign rank p-value } \\
\mathrm{N}\end{array}$ & $\begin{array}{l}2.59 \% \\
(0.00)^{* * * *} \\
2.02 \% \\
(0.00)^{* * *} \\
46\end{array}$ & $\begin{array}{l}2.65 \% \\
(0.00)^{* * * *} \\
2.22 \% \\
(0.01)^{* * * *} \\
37\end{array}$ & $\begin{array}{l}2.36 \% \\
(0.02)^{* *} \\
1.83 \% \\
(0.02)^{* *} \\
9\end{array}$ & $\begin{array}{l}(0.71) \\
(0.80)\end{array}$ \\
\hline \multicolumn{5}{|c|}{ Panel B: Parent firm retention sample classified by takeover activity in the carve-out } \\
\hline & $\begin{array}{l}\text { Full } \\
\text { retention } \\
\text { sample }\end{array}$ & $\begin{array}{l}\text { Carve-out } \\
\text { not subsequently } \\
\text { taken over } \\
\text { within six years }\end{array}$ & $\begin{array}{l}\text { Carve-out } \\
\text { subsequently } \\
\text { taken over } \\
\text { within six years }\end{array}$ & $\begin{array}{l}\text { Difference } \\
\text { of } \\
\text { means, } \\
\text { medians }\end{array}$ \\
\hline $\begin{array}{l}\text { Mean } \\
t \text {-statistic p-value }{ }^{b} \\
\text { Median } \\
\text { Sign rank p-value } \\
\mathrm{N}\end{array}$ & $\begin{array}{l}1.28 \% \\
(0.01)^{* * * *} \\
0.75 \% \\
(0.01)^{* * *} \\
126\end{array}$ & $\begin{array}{l}0.78 \% \\
(0.04)^{* *} \\
0.37 \% \\
(0.12) \\
144\end{array}$ & $\begin{array}{l}4.12 \% \\
(0.07)^{*} \\
2.04 \% \\
(0.06)^{*} \\
28\end{array}$ & $\begin{array}{l}(0.08)^{*} \\
(0.01)^{* * *}\end{array}$ \\
\hline $\begin{array}{l}\text { Difference of means } \\
\text { Difference of medians }\end{array}$ & $\begin{array}{l}(0.04)^{* *} \\
(0.09)^{*}\end{array}$ & $\begin{array}{l}(0.01)^{* * *} \\
(0.06)^{*}\end{array}$ & $\begin{array}{l}(0.82) \\
(0.48)\end{array}$ & \\
\hline \multicolumn{5}{|c|}{$\begin{array}{l}\text { Excess returns are calculated using the market model, where }(-210,-121) \text { serves as the estimation period. } \\
\text { The } t \text {-statistics test the hypothesis that the mean holding-period returns equal zero: } * \text { denotes significance at the } 10 \% \text { level, } \\
\text { and } * * \text { denotes significance at the } 5 \% \text { level, and } * * * \text { denotes significance at the } 1 \% \text { level. } \\
\text { The two-tailed Wilcoxon signed rank statistics (Sign Rank) test the null hypothesis that the median industry-adjusted rates are } \\
\text { equal to zero: } * \text { denotes significance at the } 10 \% \text { level, and } * * \text { denotes significance at the } 5 \% \text { level, and } * * * \text { denotes } \\
\text { significance at the } 1 \% \text { level. }\end{array}$} \\
\hline
\end{tabular}




\section{Conclusions}

This paper argues a corporate control hypothesis in which equity carve-outs facilitate takeovers by providing an economical means to transfer control of corporate assets to bidders who will potentially create greater value. By splitting companies into separate businesses, equity carve-outs allow bidders who are able to create more value to avoid the expense of taking over whole entities.

Consistent with this hypothesis, I find a high incidence of subsequent takeovers of carved-out subsidiaries. Sixteen percent of this study's sample is taken over within the six years, a proportion that is statistically greater than the nine percent found for a matched firm group. Those carve-outs subsequently taken over appear to be economically different from those carve-outs not subsequently taken over, with those taken over generating significantly higher gains to parent firm shareholders, on average. One factor that contributes to parent firm gains of carve-outs subsequently taken over is the relative size of the carve-out IPO. The higher the relative proportion of the carve-out sold to the market, up to a point, the higher the gains to parent firm shareholders. An important implication of this investigation is that there appears to be an optimal parent retention level for the carve-out IPOs motivated by the intent to facilitate changes in corporate control. For those parents retaining 10-50\% of their subsidiaries, gains to shareholders are highest.

\section{Suggestions for future research}

This paper finds that one factor that contributes to parent firm gains of carve-outs subsequently taken over is the relative size of the carve-out IPO. One suggestion for future research is to examine whether there are other factors that contribute to these parent firm gains. For example, carve-outs that are subsequently taken over might be economically different from those that are not, based on growth opportunities, profitability, and / or relatedness to the parents' industry. Future research might also examine whether parent firms tend to be taken over in the same cases as their carved-out subsidiaries. This could occur if a parent's divestiture of an unrelated subsidiary makes both the parent and the subsidiary more attractive as takeover targets.

\section{Endnotes}

1 When an equity carve-out is taken over, the parent gets a portion of the takeover premium since the parent retains an ownership stake in its carved-out subsidiary.

2 By retaining at least 50\%, the parent firm can consolidate the subsidiary for financial reporting purposes. By retaining at least $80 \%$, the parent firm can consolidate the subsidiary for tax purposes, and can obtain a $100 \%$ dividend-received tax deduction.

3 Some firms report at the announcement what their intentions are in this regard; most do not.

\section{References}

1. Allen, Jeffrey W. and John J. McConnell, "Equity carve-outs and managerial discretion," The Journal of Finance, Vol. 53, pp. 163-186, 1998.

2. Aron, Debra J., "Using the capital market as a monitor: Corporate spin-offs in an agency framework," The Rand Journal of Economics, Vol. 22, pp. 505-518, 1991.

3. Chatterjee, Sris, Upinder S. Dhillon, and Gabriel G. Ramirez, "Coercive tender and exchange offers in distressed high-yield debt restructurings: An empirical analysis," Journal of Financial Economics, Vol. 38, pp. 333-360, 1995.

4. Cusatis, Patrick, James A. Miles, and J. Randall Woolridge, "Restructuring through spin-offs: The stock market evidence," Journal of Financial Economics, Vol. 33, pp. 293-311, 1993.

5. Gilson, Stuart C., Paul M. Healy, Christopher F. Noe, and Krishna Palepu, "Analyst specialization and conglomerate stock breakups," Journal of Accounting Research, Vol. 39, pp. 565-582, 2001.

6. Gilson, Stuart C., Kose John, and Larry N. P. Lang, "Troubled debt restructuring: An empirical study of private reorganization of firms in default," Journal of Financial Economics, Vol. 27, pp. 315-354, 1990. 
7. Hite, Gailen L., and James E. Owers, "Security price reactions around corporate spin-off announcements," Journal of Financial Economics, Vol. 12, pp. 409-436, 1983.

8. James, Christopher, "Bank debt restructurings and the composition of exchange offers in financial distress," The Journal of Finance, Vol. 51, pp. 711-727, 1996.

9. Jensen, Michael C. and Richard S. Ruback, "The market for corporate control: The scientific evidence," Journal of Financial Economics, Vol. 11, pp. 5-50, 1983.

10. Lang, Larry, Annette Poulsen, and Rene Stulz, "Asset sales, firm performance, and the agency costs of managerial discretion," Journal of Financial Economics, Vol. 37, pp. 3-37, 1995.

11. Miles, James A. and James D. Rosenfeld, "The effect of voluntary spin-off announcements on shareholder wealth," The Journal of Finance, Vol. 38, pp. 1597-1606, 1983.

12. Myers, Stewart and Nicholas Majluf, "Corporate financing and investment decisions when firms have information that investors do not have," Journal of Financial Economics, Vol. 13, pp. 187-221, 1984.

13. Nanda, Vikram, "On the good news in equity carve-outs," The Journal of Finance, Vol. 46, pp. 1717-1736, 1991.

14. Schipper, Katherine and Abbie Smith, "Effects of recontracting on shareholder wealth: The case of voluntary spin-offs," Journal of Financial Economics, Vol. 12, pp. 437-467, 1983.

15. Schipper, Katherine and Abbie Smith, "A comparison of equity carve-outs and seasoned equity offerings," Journal of Financial Economics, Vol. 15, pp. 153-186, 1986.

16. Slovin, Myron B., Marie E. Sushka, and Steven R. Ferraro, "A comparison of the information conveyed by equity carve-outs, spin-offs, and asset sell-offs," Journal of Financial Economics, Vol. 37, pp. 89-104. 1995.

Notes 


\section{Do Not Print This Page!!}

\section{EndNotes}

\footnotetext{
${ }^{1}$ When an equity carve-out is taken over, the parent gets a portion of the takeover premium since the parent retains an ownership stake in its carved-out subsidiary.

${ }^{2}$ By retaining at least $50 \%$, the parent firm can consolidate the subsidiary for financial reporting purposes. By retaining at least $80 \%$, the parent firm can consolidate the subsidiary for tax purposes, and can obtain a $100 \%$ dividend-received tax deduction.

${ }^{3}$ Some firms report at the announcement what their intentions are in this regard; most do not.
} 